\title{
On the economic nature of consumers' willingness to pay for a selective and sustainable fishery: A comparative empirical study
}

\author{
Laura Onofri ${ }^{1}$, Paolo Accadia ${ }^{2}$, Paloma Ubeda ${ }^{3}$, Maria-José Gutiérrez ${ }^{4}$, Evelina Sabatella ${ }^{2}$, \\ Francesc Maynou ${ }^{5}$ \\ ${ }^{1}$ Department of Land, Environment, Agriculture and Forestry, University of Padua, 35122 Padua, Italy. \\ (LO) (Corresponding author) E-mail: laura.onofri@unipd.it. ORCID iD: https://orcid.org/0000-0001-8962-4626 \\ ${ }^{2}$ NISEA Fisheries and Aquaculture Economic Research, via Irno 11, Salerno, Italy. \\ (PA) E-mail: accadia@ nisea.eu. ORCID iD: https://orcid.org/0000-0003-3832-3377 \\ (ES) E-mail: e.sabatella@nisea.eu. ORCID iD: https://orcid.org/0000-0002-2129-1869 \\ ${ }^{3}$ Departamento de Economía Aplicada y Estadística, Universidad Nacional de Educación a Distancia (UNED), Madrid, Spain. \\ (PU) E-mail: paloma.ubeda@ cee.uned.es. ORCID iD: https://orcid.org/0000-0002-8497-005X \\ ${ }^{4}$ FAEII and MacLab, University of the Basque Country (UPV/HEU), Spain. \\ (M-JG) E-mail: mariajose.gutierrez@ehu.eus. ORCID iD: https://orcid.org/0000-0003-3074-0854 \\ 5 Institut de Ciències del Mar, CSIC. Psg Marítim de la Barceloneta 37-49. 08003-Barcelona, Spain. \\ (FM) E-mail: maynouf@icm.csic.es. ORCID iD: https://orcid.org/0000-0001-7200-6485
}

\begin{abstract}
Summary: The EU Landing Obligation (LO) bans discards to incentivize a more selective and sustainable fishery. This regulation may induce a cost to the fishing industry that could be transferred to final fish consumers. We aim to assess the consumers' reservation price for a sustainable and selective fishery. The methodology follows two steps: We first assess the value of the reservation price (willingness to pay, WTP) for a sustainable and selective fishery by using contingent valuation methods from a comparative perspective in Spain and Italy. We then attempt to empirically assess the components of WTP by using an original model specification that, unlike those presented in the literature, exogenizes socio-economic variables and uses ideological indicators to explain WTP in a two-line simultaneous model estimated by instrumental variable regression. The results show a positive, though low, WTP across the two samples, and very different impacts of estimated coefficients on the WTP for the two samples. A preliminary interpretation of this divergence highlights that Italian consumers consider LOincentivized sustainable fishery a pure public good linked to issues of legality, and Spanish consumers consider it an impure public good linked to environmental issues. These differences may indicate how strongly the institutions and the policies in each region are perceived by a different human capital structure. They may also indicate that the problem, the perceptions of it and the solutions to it differ according to the context.
\end{abstract}

Keywords: willingness to pay; landing obligation; discards; instrumental variable regression, contingent valuation, sustainable fishery.

Naturaleza económica de la disposición a pagar de los consumidores por una pesca más selectiva y sostenible: un estudio comparativo empírico

Resumen: La obligación de desembarque de la Unión Europea (LO) prohíbe los descartes para incentivar una pesquería más selectiva y sostenible. Esta regulación puede inducir costes a la industria pesquera que a su vez pueden ser transferidos al consumidor final. Nuestro objetivo es evaluar el precio de reserva del consumidor para una pesquería más sostenible y selectiva. La metodología se basa en dos fases: primero, evaluamos el precio de reserva (disposición a pagar, WTP) para una pesquería sostenible y selectiva mediante métodos de valoración contingente (CV) en un estudio comparativo entre España e Italia. En una segunda fase intentamos estimar empíricamente los componentes de esta WTP mediante la especificación original de un modelo que, a diferencia de la literatura existente, exogeniza las variables socioeconómicas y usa indicadores ideológicos para explicar la WTP, en una regresión bi-funcional con variables instrumentales (IV). Los resultados muestran una WTP positiva, aunque reducida, en ambas muestras, y permiten deducir un impacto distinto de los coeficientes estimados en la WTP. La interpretación preliminar de esta divergencia hace destacar que los consumidores italianos consideran como un bien público puro a una pesquería sostenible incentivada mediante LO, relacionado con aspectos de legalidad, mientras que los consumidores españoles consideran ese modelo de pesquería como un bien público impuro, relacionado con conservación ambiental. Estas diferencias pueden indicar la fortaleza con la que dos estructuras distintas de capital humano perciben las instituciones y las políticas de cada región. También sugieren una distinta percepción, existencia y solución del problema en un contexto distinto.

Palabras clave: disposición a pagar; obligación de desembarque; descartes; regresión con variables instrumentales; valoración contingente, pesca sostenible. 
Citation/Como citar este artículo: Onofri L., Accadia P., Ubeda P., Gutiérrez M.-J., Sabatella E., Maynou F. 2018. On the economic nature of consumers' willingness to pay for a selective and sustainable fishery: A comparative empirical study. Sci. Mar. 82S1: 91-96. https://doi.org/10.3989/scimar.04737.10A

Editor: P. Martín.

Received: December 1, 2017. Accepted: May 25, 2018. Published: June 15, 2018.

Copyright: (C) 2018 CSIC. This is an open-access article distributed under the terms of the Creative Commons Attribution 4.0 International (CC BY 4.0) License.

\section{INTRODUCTION}

The EU Landing Obligation (LO, reformed Common Fisheries Policy: EU Reg. 1380/2013) introduced a gradual obligation to land discards of certain regulated species according to a well-established schedule in different European marine regions, fisheries and species. The LO aims to incentivize fishers to adopt more selective, discard-minimizing techniques for the preservation and conservation of marine resources. To allow fishers to adapt to the changes, the EU regulation will be implemented progressively between 2015 and 2019 for all commercial fisheries in European waters. The LO applies to species subject to catch limits (in the Atlantic) and species subject to minimum size limits (in the Mediterranean). The LO will be implemented through discard plans that include the species covered, provisions on catch documentation, minimum conservation reference sizes and exemptions (for fish that may survive after being released back at sea), and a specific de minimis discard allowance under certain conditions (EU Reg. 1380/2013).

The implementation of the LO may involve a cost arising from the need to adopt new technologies and fishing gears. The social costs of a sustainable fishery must be supported by private, though partially subsidized, investments. Fishers may transfer these costs to the consumers by increasing the price of the final product. Potential price increases are therefore "green" mark-ups that consumers might be willing to pay in order to conserve and preserve marine resources.

In the present study, a sample of Italian and Spanish fish consumers were asked to state their willingness to pay (WTP) in order to be informed and receive guarantees that the fish they buy was caught according to selective and sustainable fishing techniques encouraged by the LO.

The paper has a twofold aim. First, it adopts a stateof-the-art methodology for the quantitative computation of the consumers' reservation price for selective and sustainable fishery. Second, it aims to obtain insights from this quantitative assessment by empirically modelling and assessing how ideological and psychological factors affect consumers' preferences for sustainable products in comparative settings.

\section{MATERIALS AND METHODS}

\section{Dataset formation}

The impacts of the LO are not incorporated in market dynamics, since the regulation is not yet fully implemented and in force. We therefore adopted contingent valuation (CV) methods that assess the WTP for sustainable and selective fisheries that are incentivized by the LO. The WTP for selective and sustainable fisheries provides important information, constructed with primary data, on the respondent's reservation price for non-market characteristics of the fish. The state-of-the-art CV method and its refinements allow the consumers' reservation price for non-market goods to be assessed and measured. However, the disadvantage of this well-established method lies in the controversial interpretation of stated preferences expressed in monetary terms as "non-real" economic preferences. Furthermore, WTP elicitation through CV studies is contingent to the moment when the survey is administered. Nevertheless, with the caveats highlighted in the discussion, we selected this method because of the clear efficacy and simplicity of the mechanism that elicits preferences for non-market goods.

$\mathrm{CV}$ relies mostly on the use of administered surveys that gather information and data, including WTP. In our study, data were gathered through surveys constructed using a three-step procedure that was standardized by the NOAA Panel on Contingent Valuation (1993) and is widely discussed in the economics literature (see Carson et al. 1992, Diamond et al. 1993, Kahneman and Knetsch 1992, among others). The first step was to gain background information on the topic by reading laws and regulations and talking to experts. The second step was to draft a preliminary questionnaire to be distributed for validation and correction to a focus group of experts at the Spanish National Council for Scientific Research (CSIC) in Barcelona, in December 2016. The third step was to define the final draft of the questionnaire and carry out the surveys.

The questionnaire was divided into four parts. The first part presented selected "ideological issues" about which the respondent was required to give an opinion (ranging from not important to very important). The rationale behind this group of questions was twofold. First, it aimed to profile and understand the ideological positioning of the respondents (see Nunes and Shokkaert 2003). Second, it aimed to deal with the contradictory behaviour that is usually identified in respondents of CV surveys (see Onofri et al. 2010). For instance, $\mathrm{CV}$ respondents in environmental non-market goods studies might claim to support social/environmental causes that are generally based on collective aims, but the ideological support might not be confirmed by an economic preference expressed in monetary terms. The second part of the survey aimed to understand the consumption habits of the respondents. The third part 
of the survey was dedicated to the WTP elicitation. Respondents were asked to state how much more they would have liked to pay (in \% of the price of the most consumed fish per kilogram) to be informed and receive guarantees that the fish was caught according to selective and sustainable fishing techniques. The percentage increase was bounded in the range between $0 \%$ and 50\%. Following the NOAA's recommendations, the problem and scenarios were presented shortly and clearly. Respondents were confronted with an economic trade-off: on the one hand, the benefit of being able to purchase a more sustainable product and being informed about it; on the other hand, the cost of having to pay a higher price for the product. CV methods aim to construct a datum in a non-market context in which the demand function does not exist. In this context, the demand function, as a repository of value, can be latent and describe important behavioural relations expressed in monetary terms. The conceptual link to non-market valuation is the recognition that, while a demand curve is not observable if there is no market for a commodity, there still exists a latent demand curve that can perhaps be teased out through other means. In addition, the validity of the method has been thoroughly scrutinized. The 1993 NOAA Panel rejected as unwarranted the claim that $\mathrm{CV}$ surveys can never be a reliable source of information either for benefit cost analysis or for damage assessment (see Hanemann 1993). Finally, the fourth part of the survey included questions on selected socio-economic characteristics of the respondents (gender, age, income class, education level, and so on).

The surveys were administered in Salerno, southern Italy (the Campania Region), in the period JanuaryFebruary 2017 and in Bilbao, northern Spain (the Basque Country) in the period February-March 2017. In Salerno, the surveys were administered in person at different points of the city, including the local fish markets. In Bilbao, the surveys were administered via e-mail, with a random sample selection of staff members of the University of the Basque Country. A total of 167 (Salerno) and 232 (Bilbao) compiled surveys were gathered. The survey information was transferred to an Excel template created ad hoc to facilitate and homogenize the researchers' work. Datasets were finally transferred to STATA 12 for statistical and econometric analysis.

\section{Selected descriptive statistics}

The selected descriptive statistics are reported in Table 1.

\section{Empirical strategy}

Once the WTP for selective and sustainable fishery had been computed, we wished to estimate the impacts of ideological variables on the value. The reason behind the research choice and the empirical strategy was twofold. First, we wanted to tackle an understudied problem in the literature (see Nunes and Shokkaert 2003) and to assess how and (how much) ideological issues affect the formation of reservation prices in non-market goods settings, where the monetary value of preferences is (with many methodological and theoretical caveats) stated and not revealed by consumption choices as in the marketplace. Second, we wanted to add an original piece of research by using an empirical modelling strategy unlike that of other studies (see Olesen et al. 2010, Loureiro and Umberger 2003, Brecard et al. 2009, among the others), in which WTP is mostly modelled and estimated using linear models and/or as univariate/multivariate probabilistic specifications.

In our study, we acknowledge that the WTP for non-market goods or for the non-market components of market goods depends, first, on a set of endogenous variables that are determined within the empirical model and together with the dependent variable WTP and, second, on a set of exogenous variables that are predetermined and instrumental. This modelling strategy follows the intuition that the WTP is determined by the $\mathrm{CV}$ of the respondent in the moment the person is interviewed, but this valuation also depends on the respondent's profile, which is predetermined by life experience, personal taste and budget constraints, among other variables. The modelling partially addresses the criticism of $\mathrm{CV}$, because contingent stated preferences are "framed" in a consolidated market consumption behaviour (purchase of the fish most consumed in the household). In addition, we exogenize the respondents' socio-economic profile, which is predetermined with respect to the $\mathrm{CV}$ exercise.

The empirical specification is summarized in Equation 1 .

$$
W T P_{\mathrm{i}}=\alpha+\beta X i+\mu Z_{\mathrm{i}}+v_{\mathrm{i}}
$$

WTP is the ith respondent stated preference expressed in monetary terms and is a variable that we have constructed through the administration of surveys, using the CV methodological framework. Our work differs from similar studies because we asked respondents to compute their reservation price for a non-market good (a sustainable and selective fishery) as a percentage mark-up on the price of a market good that they usually purchase, for the sake of minimizing arbitrary answers. The vector $X i$ contains endogenous variables and the vector $Z_{\mathrm{i}}$ includes exogenous, instrumental variables. The parameters to be estimated are $\beta$ and $\mu$. The model includes a constant and an error term.

\section{RESULTS}

The comparative results of the survey are presented in Table 2. The estimates show that the respondents' stated WTP is positively/negatively affected by a set of endogenous ideological variables that, in turn, are determined by a set of instrumental socio-economic variables (respondent's age; gender (being female); job; income level; having a partner; and decisions on how much to spend on fish per month and how many times to consume fish in a month). Attaching great importance to marine protection and conservation for future generations has a negative and positive effect on 
Table 1. - Descriptive Statistics. The source of Italian prices is the Italian Institute of Services for the Agricultural Food Market (ISMEA). The source of Spanish prices is the University of the Basque Country.

\begin{tabular}{|c|c|c|}
\hline Questions/Variables & $\begin{array}{c}\text { Salerno } \\
\text { (Campania, Italy) }\end{array}$ & $\begin{array}{c}\text { Bilbao } \\
\text { (Basque Country, Spain) }\end{array}$ \\
\hline \multicolumn{3}{|l|}{ A. IDEOLOGICAL } \\
\hline $\begin{array}{l}\text { Marine Protection/conservation for future genera- } \\
\text { tions is very important }\end{array}$ & $78 \%$ & $92.24 \%$ \\
\hline $\begin{array}{l}\text { Availability of fish at affordable prices for every- } \\
\text { one is very important }\end{array}$ & $63 \%$ & $58 \%$ \\
\hline $\begin{array}{l}\text { High fish quality, even if very expensive, is very } \\
\text { important }\end{array}$ & $48 \%$ & $47 \%$ \\
\hline Combating illegal fishing is very important & $66 \%$ & $77 \%$ \\
\hline $\begin{array}{l}\text { Certification of caught fish and geographic prov- } \\
\text { enance is very important }\end{array}$ & $84 \%$ & $62 \%$ \\
\hline \multicolumn{3}{|l|}{ B. CONSUMPTION HABITS } \\
\hline Most consumed species & $\begin{array}{c}\text { anchovy }(12.73 \%) \\
\text { seabass }(9.70 \%) \\
\text { seabream }(16.36 \%)\end{array}$ & $\begin{array}{c}\text { hake }(50.43 \%) \\
\text { anchovy }(7.33 \%) \\
\text { cod }(10.34 \%) \\
\text { seabass }(7.33 \%)\end{array}$ \\
\hline Preferred species & $\begin{array}{c}\text { anchovy }(15.15 \%) \\
\text { hake }(11.52 \%) \\
\text { seabass }(13.94 \%) \\
\text { seabream }(15.76 \%)\end{array}$ & $\begin{array}{l}\text { hake }(50.43 \%) \\
\text { seabass }(12.50 \%) \\
\text { salmon }(10.34 \%)\end{array}$ \\
\hline Habit formation & $\begin{array}{c}\text { household as kids }(21.82 \%) \\
\text { personal taste }(62.67 \%) \\
\text { learning and experience }(10.91 \%)\end{array}$ & $\begin{array}{c}\text { household as kids }(43.53 \%) \\
\text { personal taste }(18.53 \%) \\
\text { learning and experience }(13.79 \%)\end{array}$ \\
\hline Monthly expenditure for fish in the household & $\begin{array}{c}€ 80 \text { (average) } \\
0(\text { minimum }) \\
€ 500 \text { (maximum) }\end{array}$ & $\begin{array}{c}€ 92 \text { (average) } \\
0 \text { (minimum) } \\
€ 1000 \text { (maximum) }\end{array}$ \\
\hline Monthly consumption frequency & $\begin{array}{c}5 \text { times (average) } \\
0 \text { times (minimum) } \\
12 \text { times (maximum) }\end{array}$ & $\begin{array}{c}8-9 \text { times (average) } \\
0 \text { times (minimum) } \\
25 \text { times (maximum) }\end{array}$ \\
\hline Purchase of certified fish & $44.3 \%$ & $86.55 \%$ \\
\hline $\begin{array}{l}\text { Happy (share of respondents that consume the } \\
\text { preferred fish) }\end{array}$ & $46.03 \%$ & $42.24 \%$ \\
\hline \multicolumn{3}{|c|}{ C. WTP FOR SUSTAINABLE AND SELECTIVE FISHERY } \\
\hline $\begin{array}{l}\text { WTP as a \% amount over the price per kilo of the } \\
\text { most consumed fish }\end{array}$ & $13.73 \%$ (mean) & $15.88 \%($ mean $)$ \\
\hline WTP expressed in monetary terms & $\begin{array}{l}€ 1.80(\text { mean }) \\
0 \text { (minimum) } \\
\quad € 7.5\end{array}$ & $\begin{array}{c}€ 1.04 \text { (mean) } \\
0 \text { (minimum) } \\
€ 3.72 \text { (maximum) }\end{array}$ \\
\hline \multicolumn{3}{|l|}{ D. SOCIO-ECONOMICS } \\
\hline Nationality & Italian $(98.81 \%)$ & Spanish $(97.94 \%)$ \\
\hline Gender & Female $(61.31 \%)$ & Female $(68.53 \%)$ \\
\hline Age & $\begin{array}{l}49 \text { (mean) } \\
20 \text { (minimum) } \\
90 \text { (maximum) }\end{array}$ & $\begin{array}{c}40 \text { (mean) } \\
19 \text { (minimum) } \\
65 \text { (maximum) }\end{array}$ \\
\hline Civil status & Single $(30.72 \%)$ & Single $(51.29 \%)$ \\
\hline Number of children in the household & $\begin{array}{c}1 \text { (mean) } \\
0 \text { (minimum) } \\
6 \text { (maximum) }\end{array}$ & $\begin{array}{l}0.51 \text { (mean) } \\
0 \text { (minimum) } \\
4 \text { (maximum) }\end{array}$ \\
\hline Educational level & $\begin{array}{l}\text { upper secondary school }(44 \%) \\
\text { bachelor's degree }(40 \%)\end{array}$ & $\begin{array}{l}\text { upper secondary school }(18.43 \%) \\
\text { bachelor's degree }(42.24 \%)\end{array}$ \\
\hline Job & $\begin{array}{c}\text { Public/private office worker }(30 \%) \\
\text { homemaker }(12.60 \%), \\
\text { retired }(10.60 \%), \\
\text { teacher }(6.30 \%), \\
\text { student }(5.70 \%), \\
\text { entrepreneur }(8.20 \%), \\
\text { liberal professions }(20.20 \%), \\
\text { manual worker }(3.20 \%), \\
\text { other }(3.20 \%)\end{array}$ & $\begin{array}{c}\text { student }(22 \%), \\
\text { teacher }(37.50 \%), \\
\text { administrative officer }(9 \%) \text {, } \\
\text { liberal professions }(9.46 \%) \text {, } \\
\text { other }(22.04 \%)\end{array}$ \\
\hline Income range (household monthly net income) & $\begin{array}{l}€ 1000-2500(64.52 \%) \\
2500-€ 4000(20 \%)\end{array}$ & $\begin{array}{l}€ 1000-2500(29.74 \%) \\
€ 2500-4000(34.48 \%)\end{array}$ \\
\hline
\end{tabular}

the individual WTP for sustainable products and information on sustainable fishing techniques in Italy and Spain, respectively.
Attaching great importance to the issue of combating illegal fishing (one of the UN Sustainable Development Goals) has a positive effect on the WTP for sus- 
Table 2. - Instrumental variable estimation of WTP for sustainable fish.

\begin{tabular}{lcc}
\hline Explanatory variables & $\begin{array}{c}\text { Estimated coefficients } \\
\text { Italy }\end{array}$ & $\begin{array}{c}\text { Estimated coefficients } \\
\text { Basque Country }\end{array}$ \\
\hline A1. Marine Protection/conservation for future generations & $-0.88 * * *$ & $1.57 * * *$ \\
A4. Combating illegal fishing & $1.17 * * *$ & -0.17 \\
A5. Certification of caught fish and geographic provenance & $-1.01 * * *$ & $0.71 * * *$ \\
Constant & 2.75 & 3.71 \\
\hline
\end{tabular}

Instruments: number of children, age, female, job, income, partner, (log)monthly expenditures for fish, (log)monthly consumption for fish, habits, happy. Number of children, number of children in the household; age, age of the respondent; female, dummy for gender; income, respondents' net household income category; partner, dummy for household composition; (log)monthly expenditures for fish, monthly expenditure for fish expressed in logarithms; (log)monthly consumption for fish, monthly frequency of consumption expressed in logarithms; habits, reasons that formed the alimentary habits; happy, dummy that equals 1 when most consumed and preferred fish coincide. $* * *, 1 \%$ statistically significant.

tainable resources in Italy and a negative one in Spain. Attributing great importance to certification of quality and geographical provenance has a positive effect on the WTP in Spain and a negative one in Italy.

\section{DISCUSSION}

Ideological variables might help to understand the respondent's preference structure, expressed in monetary terms, in the samples under scrutiny. We chose three variables that rely on the good functioning of the institutions and the markets and used them as explanatory variables for the WTP for sustainable and selective fishery practices that should be generated and incentivized by the LO. The results differed substantially for the two samples considered, for reasons that we will analyse in more detail in future research. The modelling strategy and exogenization of socio-economic characteristics, however, isolate and partially solve the problem of sample diversity. A preliminary interpretation of this divergence highlights that Italians consider LO-incentivized sustainable fishery as a pure public good, linked to issues of legality, and Spaniards consider it as an impure public good linked to environmental issues. These differences may indicate how strongly the institutions and the policies in each region are perceived by a different human capital structure. They may also indicate that the problem, the perceptions of it and the solutions to it differ according to the context. Illegal fishing, for instance, has negative effects (e.g. a health risk) and losses (e.g. missed revenues).

In Italy, great concern for this problem is associated with a higher reservation price for a sustainable and selective fishery. The opposite effect is observed and quantified within the Spanish sample, suggesting that, even though the Spanish consider combating illegal fishing an important topic, they do not feel responsible for paying for it, most probably because they consider the problem to have little relation or because illegal, unreported and unregulated fishing (IUU) is not an urgent issue in the Basque Country. The opposite holds for Italians, who related illegal fishing to a sustainable and selective fishery and feel responsible for paying for the direct benefits arising from combating IUU: alimentary security and food security.

Italians consider environmental protection and conservation of marine habitats an important issue but do not feel responsible for paying for it in order to support a sustainable and selective fishery. The opposite holds for the Spanish respondents, who attach high importance to marine conservation and preservation for future generations and feel responsible for paying for it in order to support a sustainable and selective fishery. The ideological positioning is also an economic preference and environmental protection and conservation might be interpreted as a public good. Estimates for the third explanatory variables seem to confirm the different structure of economic preferences and understanding of sustainable and selective fishery across the two samples.

Our estimates represent a contribution to the study of human preferences and behaviour with a comparative application to non-market issues in the fishery sector. However, it would be misleading to suggest that $\mathrm{CV}$ surveys can be made to work well in all circumstances and to compare our results with those of other CV studies in similar contexts. The elicitation of non-market preferences through $\mathrm{CV}$ (and their value in monetary terms) can, in fact, follow several methods and is contingent to the respondents' statements. The method, though simple in its directness, is difficult to implement without falling into various types of design problems that require effort, skill and imagination to resolve. Each particular study needs to be scrutinized carefully and, in particular, in its context. However, the same is true of any empirical study (see Hanemann 1993).

\section{ACKNOWLEDGEMENTS}

The authors thank Paulo A.L.D. Nunes for his help in defining the last version of the survey. The authors are very grateful to the two reviewers for comments and suggestions that improved the final version of the manuscript. This research was funded by EU H2020 Research and Innovation Action "MINOUW" (contract $\mathrm{n}^{\circ}$ 634495).

\section{REFERENCES}

Brecard D., Hlaimi B., Lucas S., et al. 2009. Determinants of demand for green products: An application to eco-label demand for fish in Europe. Ecol. Econ. 69: 115-125. https://doi.org/10.1016/j.ecolecon.2009.07.017

Carson R., Cameron R., Hanemann M., et al. 1992. A Contingent Valuation Study of Lost Passive Use Values Resulting from the Exxon Valdez Oil Spill. A Report for the Attorney General of the State of Alaska; November 19, 1992. 133 pp.

Diamond P. 1993. Experimental evidence. In: Hausman J. (ed.), Contingent valuation: a critical assessment, North Holland 
Press. Amsterdam.

Hanemann M. 1993. Valuing the environment through continent valuation. J. Econ. Perspect. 8: 19-43. https://doi.org/10.1257/jep.8.4.19

Kahneman D., Knetsch J. 1992. Valuing Public Goods: The Purchase of Moral Satisfaction. J. Environ. Econ. Manage. 22: $57-70$

https://doi.org/10.1016/0095-0696(92)90019-S

Loureiro M., Umberger W.J. 2003. Estimating consumer willingness to pay for country-of-origin labeling, J. Agr. Resour. Econ. 28: 287-301.

Nunes P.A.L.D., Shokkaert E. 2003. Identifying the warm glow effect in contingent valuation. J. Environ. Econ. Manage. 45: 231-245.

https://doi.org/10.1016/S0095-0696(02)00051-7

Olesen I., Alfnes F., Rora M.B., et al. 2010. Eliciting consumers' willingness to pay for organic and welfare-labelled salmon in a non-hypothetical choice experiment. Livestock Sci. 127: 218-226. https://doi.org/10.1016/j.livsci.2009.10.001

Onofri L. Nunes P.A.L.D., Cenoz J., et al. 2010. Economic Preferences for Language Diversity: A Myth or Reality? An Attempt to Estimate the Economic Value of the Linguistic Landscape. Fondazione Eni Enrico Mattei. SusDiv Paper 15. 